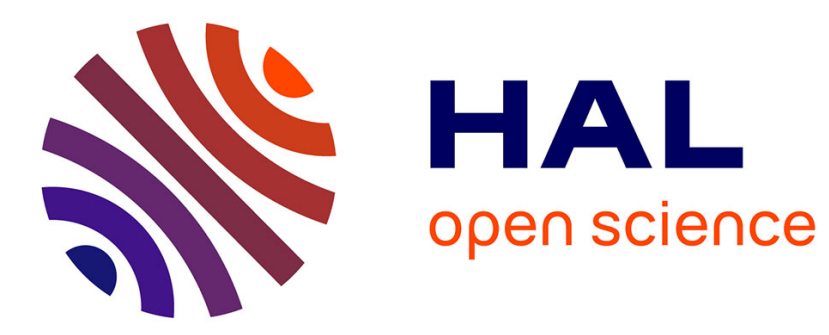

\title{
Deposition of artificial radionuclides from atmospheric Nuclear Weapon Tests estimated by soil inventories in French areas low-impacted by Chernobyl
}

\author{
Gaël Le Roux, Céline Duffa, Françoise Vray, Philippe Renaud
}

\section{To cite this version:}

Gaël Le Roux, Céline Duffa, Françoise Vray, Philippe Renaud. Deposition of artificial radionuclides from atmospheric Nuclear Weapon Tests estimated by soil inventories in French areas lowimpacted by Chernobyl. Journal of Environmental Radioactivity, 2010, vol. 101, pp. 211-218. 10.1016/j.jenvrad.2009.10.010 . hal-00977781

HAL Id: hal-00977781

https://hal.science/hal-00977781

Submitted on 11 Apr 2014

HAL is a multi-disciplinary open access archive for the deposit and dissemination of scientific research documents, whether they are published or not. The documents may come from teaching and research institutions in France or abroad, or from public or private research centers.
L'archive ouverte pluridisciplinaire HAL, est destinée au dépôt et à la diffusion de documents scientifiques de niveau recherche, publiés ou non, émanant des établissements d'enseignement et de recherche français ou étrangers, des laboratoires publics ou privés. 


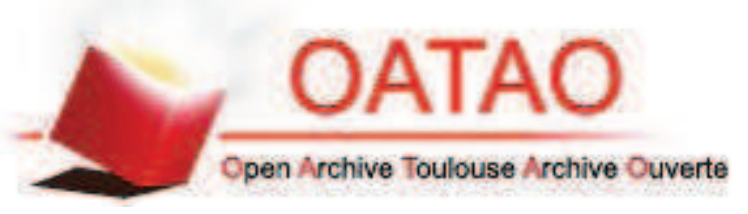

\section{Open Archive TOULOUSE Archive Ouverte (OATAO)}

OATAO is an open access repository that collects the work of Toulouse researchers and makes it freely available over the web where possible.

This is an author-deposited version published in : http://oatao.univ-toulouse.fr/ Eprints ID : 11365

To link to this article : DOI: $10.1016 /$ j.jenvrad.2009.10.010

http://dx.doi.org/10.1016/j.jenvrad.2009.10.010

To cite this version Le Roux, Gaël and Duffa, Céline and Vray, Françoise and Renaud, Philippe Deposition of artificial radionuclides from atmospheric Nuclear Weapon Tests estimated by soil inventories in French areas low-impacted by Chernobyl. (2010) Journal of Environmental Radioactivity, vol. 101 (n $\left.{ }^{\circ} 3\right)$. pp. 211218. ISSN 0265-931X

Any correspondance concerning this service should be sent to the repository administrator: staff-oatao@,1istes-diff.inp-toulouse.fr 


\title{
Deposition of artificial radionuclides from atmospheric Nuclear Weapon Tests estimated by soil inventories in French areas low-impacted by Chernobyl
}

\author{
Gaël Le Roux*, Céline Duffa, Françoise Vray ${ }^{1}$, Philippe Renaud \\ Institut de Radioprotection et Sûreté Nucléaire, DEI/SESURE, Laboratoires d'Etudes Radioécologiques en milieu Continental et Marin, \\ CEN Cadarache Bât. 153 BP 3, 13115 St Paul lez Durance, France
}

Keywords:

Atmospheric deposition

${ }^{137}$ CS

Plutonium

Americium

Nuclear Weapon Tests

France

\begin{abstract}
A B S T R A C T
Soil inventories of anthropogenic radionuclides were investigated in altitudinal transects in 2 French regions, Savoie and Montagne Noire. Rain was negligible in these 2 areas the days after the Chernobyl accident. Thus anthropogenic radionuclides are coming hypothetically only from Global Fallout following Atmospheric Nuclear Weapon Tests. This is confirmed by the isotopic signatures $\left({ }^{238} \mathrm{Pu} /{ }^{239+240} \mathrm{Pu}\right.$; ${ }^{137} \mathrm{Cs} /{ }^{239+240} \mathrm{Pu}$; and ${ }^{241} \mathrm{Am} /{ }^{239+240} \mathrm{Pu}$ ) close to Global Fallout value. In Savoie, a peat core age-dated by ${ }^{210} \mathrm{~Pb}_{\mathrm{ex}}$ confirmed that the main part of deposition of anthropogenic radionuclides occurred during the late sixties and the early seventies. In agreement with previous studies, the anthropogenic radionuclide inventories are well correlated with the annual precipitations. However, this is the first time that a study investigates such a large panel of annual precipitation and therefore of anthropogenic radionuclide deposition. It seems that at high-altitude sites, deposition of artificial radionuclides was higher possibly due to orographic precipitations.
\end{abstract}

\section{Introduction}

Artificial radionuclides in soils of Western Europe are mainly due to global fallout from Nuclear Weapon Tests (NWTs) in the late fifties and sixties, to the American SNAP 9A satellite explosion in 1964, and to deposition from Chernobyl accident in May 1986. To discriminate and evaluate separately these three causes of soil contamination, different strategies were considered in the past:

- measurements of soils before and after 1986 (e.g. Aoyama et al., 2006),

- measurements of radionuclide or radionuclide ratio specific of one event (e.g. Mitchell et al., 1990),

- use of rain-deposition map considering that annual precipitations have driven the deposition of artificial radionuclides due to global fallout and that precipitations at the beginning of May

\footnotetext{
* Corresponding author. Present address: EcoLab/Campus Ensat, Avenue de l'Agrobiopole, BP 32607, Auzeville tolosane, 31326 Castanet-Tolosan, France. Tel.: +33 (0) 5621939 40; fax: +33 (0) 562193901

E-mail address: gael.leroux@ensat.fr (G. Le Roux).

1 Dedicated to the memory of Françoise Vray.
}

1986 have driven deposition of artificial radionuclides after the Chernobyl accident (e.g. Almgren et al., 2006).

In France, no reliable maps for artificial radionuclides in soils before 1986 were available and therefore Renaud et al. (2003) used annual precipitation map and map of precipitation of 1-5 May 1986 to estimate respectively global fallout deposition and Chernobyl deposition. To estimate global fallout, Renaud et al. used the relationship established in Ireland (Mitchell et al., 1990), which is based on ${ }^{134} \mathrm{Cs} /{ }^{137} \mathrm{Cs}$ ratio considering that there was no ${ }^{134} \mathrm{Cs}$ in western Europe coming from Nuclear Weapon Test (NWT). It appeared that some French areas were theoretically unaffected by wet deposition of artificial radionuclides from Chernobyl accident.

We investigate soil inventories of artificial radionuclides in two of these areas: Savoie and Montagne Noire. In addition, these 2 areas are mountain ranges and give us information on how the deposition of artificial radionuclides was in altitude sites. Finally, the contamination of the Montagne Noire was already investigated by a non-profit organisation (CRIIRAD, 2003) and it was shown that the contamination was quite high in the soil up to $1800 \mathrm{~Bq} \mathrm{~kg}^{-1}$ for ${ }^{137}$ Cs.

The aims of this research study were 1) to validate rain-deposition estimation of global fallout and check if there were also 
artificial radionuclides from Chernobyl accident; 2) to investigate into details global fallout in mountain areas where deposition of atmospheric pollutants (POP, heavy metals) is known to be higher due to occult and orographic deposition (Graustein and Turekian, 1989; Roe, 2005; Daly and Wania, 2005; Le Roux et al., 2008).

\section{Methods}

2.1. Site description

Soils were sampled between 2004 and 2006 along transects of increasing altitude and subsequently increasing annual precipitation rate. Annual precipitation rates were given at each sampling site by data from Météo-France following AURELHY method (Bénichou and Le Breton, 1986, 1987).

Based on the map established by Renaud et al. $(2003,2004,2005)$ and RousselDebet et al. (2007), areas where no precipitation occurred in the first week of May 1986 were chosen: Savoie and Montagne Noire (Fig. 1; Table 1). These mountains have different landscape and climate features. The Montagne Noire is a smal mountain massif (Pic de Nore $-z_{\max }=1210 \mathrm{~m}$ ) in the Southern Part of Massif Central influenced both by Atlantic and Mediterranean air masses under a Mediterranean climate. Savoie (Tarentaise and Beaufortin) is a region part of the Western Alps and is characterised by a high mountain climate bordered by le Mont Blanc Massif $\left(z_{\max }=4810 \mathrm{~m}\right)$ in the North and Vanoise Massif in the South.

\subsection{Soil sampling and preparation}

Sampling sites were located in undisturbed areas, i.e. non-ploughed grassland or woodland, that were assumed flat enough (slope $<5 \%$ ) to prevent soil migration and heavy run-off erosion. In each site, undisturbed soil samples were collected using an $8 \mathrm{~cm}$ diameter stainless steel corer. Three cores (where possible) were collected together at each sampling site in order to minimize heterogeneity. The depth of each core was at least $30 \mathrm{~cm}$. Some cores were sub-sampled $(5$ or $10 \mathrm{~cm}$ ) in order to investigate the vertical distribution of the radionuclides. Sub-sections for the same depth interval of the three cores were then bulked and each composite interval was prepared separately. Soil profiles exhibiting very low anomalous inventory were discarded from data set.

Soil samples were homogenised, dried at $80^{\circ} \mathrm{C}$ and sieved to remove coarse particles (greater than $2 \mathrm{~mm}$ ) prior to spectrometry analyses. Soil samples were discarded when the amount of coarse material exceeds $30 \%$ of total material.

In addition, a peat core was taken in a minerotrophic peatland at the little Saint-Bernard Pass with a plexiglas tube of $1 \mathrm{~m}$ long and $9.4 \mathrm{~cm}$ diameter. The core was frozen, transported to the Institute of Environmental Geochemistry, Heidelberg Germany and was prepared according to the protocol of Givelet et al. (2004). The first $55 \mathrm{~cm}$ powder samples were analysed by Gamma spectrometry like soil samples.

\subsection{Gamma spectrometry}

Direct gamma spectrometry analyses were performed on closed volumes of $60 \mathrm{ml}$ of soil using $\gamma$-spectrometers with low background level HPGe-detectors with a $0.5 \mathrm{~mm}$ thickness beryllium window at the "Laboratoire de Mesure de la Radioactivité dans l'Environnement" (IRSN Orsay, France) (Bouisset and Calmet, 1997). Samples were measured for 24-48 h. Detectors were located underground, under a $3 \mathrm{~m}$ slab of concrete, in a room shielded with $10 \mathrm{~cm}$ low activity lead and $5 \mathrm{~mm}$ electrolytic copper. Efficiency calibrations were obtained using different densities of pitchblende sources prepared in the same geometry as the samples. The calibration energy range was $46 \mathrm{keV}$ to $2.7 \mathrm{MeV} .{ }^{137} \mathrm{Cs}$ activity (half-life: 30.2 years) was determined based on its peak at $661.7 \mathrm{keV}$. For peat samples, ${ }^{241} \mathrm{Am},{ }^{214} \mathrm{~Pb}$ and ${ }^{210} \mathrm{~Pb}$ were measured respectively based on their peaks at $59.4 ; 351.9$ and $46.5 \mathrm{keV}$. ${ }^{214} \mathrm{~Pb}$ was used to estimate supported ${ }^{210} \mathrm{~Pb}$ (Appleby, 2001). Self-adsorption corrections were done according to sample type, density and gamma energy using in-house standards.

\section{4. ${ }^{239+240} \mathrm{Pu}$ and ${ }^{241} \mathrm{Am}$ determination}

$\mathrm{Pu}$ isotopes and ${ }^{241} \mathrm{Am}$ were measured at the "Laboratoire de Mesure de la Radioactivité dans l'Environnement” (IRSN Orsay, France), by alpha-counting

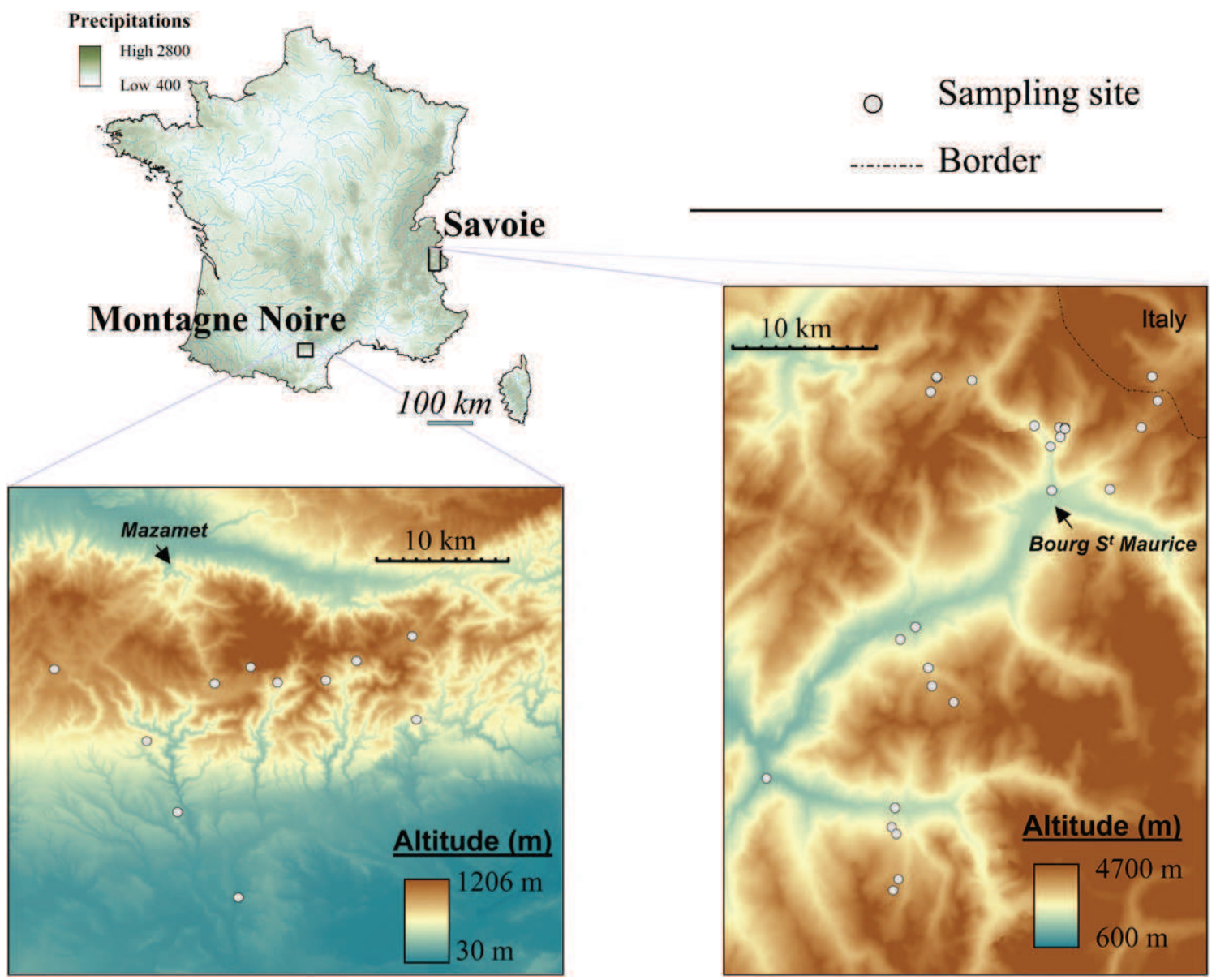

Fig. 1. Location of the sampling zones in France with respect to mean annual precipitations inferred from AURELHY Météo-France data and altitude. 
after radiochemical treatment, using a protocol of Goutelard et al. (1998). Briefly, samples are first ashed at $480^{\circ} \mathrm{C}$ in order to eliminate organic matter and then spiked with ${ }^{242} \mathrm{Pu}$ and ${ }^{243} \mathrm{Am}$, to control the recovery efficiency of the treatment. A double-step leaching using concentrated $\mathrm{HNO}_{3}$ and $\mathrm{H}_{2} \mathrm{O}_{2}$ makes the radionuclides soluble. $\mathrm{Pu}$ and $\mathrm{Am}$ are then separated from stable elements and natural alpha-emitting radioisotopes by co-precipitation exchange chromatography and extraction chromatography (Goutelard et al., 1998). The 2 fractions (respectively $\mathrm{Pu}$ and $\mathrm{Am}$ ) are then electro-deposited and alpha-counted for seven days.

\subsection{Radionuclide inventories}

Radionuclide inventories were calculated as follows:

$I=\sum_{i} A_{i} \times \delta_{i} \times z_{i} \quad($ SI units $)$

where $I$ is the total soil inventory of the measured radionuclide, $A_{i}$ the activity for the radionuclide in each layer $I$ of the $<2 \mathrm{~mm}$ dry soil fraction, $\delta_{i}$ the soil density for each layer $I$ and $z_{i}$ the depth interval for each layer $I$,

\section{Results and discussion}

\subsection{Artificial radionuclide distribution}

There is a large scale of variation in ${ }^{137} \mathrm{Cs},{ }^{239+240} \mathrm{Pu}$ and ${ }^{241} \mathrm{Am}$ inventories, for Savoie respectively $1500-8700 \mathrm{~Bq} \mathrm{~m}^{-2}$, 50$350 \mathrm{~Bq} \mathrm{~m}^{-2}$ and $20-150 \mathrm{~Bq} \mathrm{~m}^{-2}$ and for Montagne Noire respectively $2300-6900 \mathrm{~Bq} \mathrm{~m}^{-2}, 76-190 \mathrm{~Bq} \mathrm{~m}^{-2}$ and $30-73 \mathrm{~Bq} \mathrm{~m}^{-2}$.

We show that more than $60 \%$ of these radionuclides are preserved in the first $20 \mathrm{~cm}$ of the soils, ascertaining no major loss by vertical migration [ESI 1] and have the same behaviours in the soil [Fig. 2]. Because we collected soil up to at least $30 \mathrm{~cm}$ depth, we think that we get a complete recovery of the radionuclides deposited onto the soils. In addition, the similar distribution of the three elements (Cs, $\mathrm{Am}$ and $\mathrm{Pu}$ ) [for $\mathrm{Pu}$ and $\mathrm{Cs}$ relationship see Fig. 2, for $\mathrm{Am}$ and $\mathrm{Pu}$ relationship see ESI 2] indicates principally a physical, mechanical migration (i.e. bioturbation, infiltration by soil cracks...) and not a chemical migration since these elements have different chemical behaviours.

\subsection{Origin of the artificial radionuclides}

It is now well-established that ${ }^{137} \mathrm{Cs}$ from Chernobyl accident was deposited on soils mainly during raining events at the beginning of May 1986 (Almgren et al., 2006; Mitchell et al., 1990; Renaud et al., 2003). In Montagne Noire and Savoie, no precipitation occurred between 1 and 5th May 1986 and our hypothesis was that the artificial radionuclides were mainly coming from Nuclear Weapon Tests (NWTs) global fallout. This is confirmed by the mean ratio ${ }^{239-240} \mathrm{Pu} /{ }^{137} \mathrm{Cs}$ of $0.034 \pm 0.006$ (Savoie samples) [Fig. 3] compared to the ratios measured by Mitchell et al. (1990), Hodge et al. (1996) and Bunzl and Kracke (1988) between 0.03 and 0.033 . This is also confirmed by the constant values of ${ }^{239-240} \mathrm{Pu} /{ }^{137} \mathrm{Cs}$ with increasing ${ }^{137} \mathrm{Cs}$ values [Fig. 3]. Indeed any additional input of ${ }^{137} \mathrm{Cs}$ coming from Chernobyl will decrease the ${ }^{239-240} \mathrm{Pu} /{ }^{137} \mathrm{Cs}$ ratio in soils since there was negligible plutonium deposition in Western Europe after Chernobyl. Concerning ${ }^{137} \mathrm{Cs}$, the ratio to plutonium is thus constant and typical of global fallout taking into account radioactive decay until 2007.

Plutonium isotopes [Fig. 4] have a typical isotopic ratio representative of global nuclear fallout $\left({ }^{238} \mathrm{Pu} /{ }^{239+240} \mathrm{Pu}=0.0284 \pm\right.$ 0.005 for Savoie samples) which is very closed to the value of 0.03 according to Hardy et al. (1973) and soil values of $0.034 \pm 0.013$ from Italy measured by Jia et al. (1999). ${ }^{241} \mathrm{Am} /{ }^{239+240} \mathrm{Pu}$ ratio displays also relative uniform value $(0.41 \pm 0.06$ for Savoie samples) with 2 outliers from nearby sites displaying one higher value and one lower. These results are also in good agreement with soil results from South-West France (IRSN, unpublished results) [Fig. 4] and Switzerland (Eikenberg et al., 2004; Froidevaux et al., 2004).

\subsection{Relationship between soil inventories of artificial radionuclides and annual precipitations}

AURELHY ("Analyse Utilisant le RELief pour l'Hydrométéorologie") is a method of precipitation estimation based on numerous meteorological stations from Meteo France and measurements over thirty years. AURELHY method is also based on the topographic features of terrain and therefore precipitations are well correlated with altitudes for a same mountain range (Bénichou and Le Breton, 1986, 1987). The resulting map is a grid data layer at 1-km resolution with a monthly average for each point. We use it to estimate annual precipitations.

The relationships between mean annual precipitation (MAP) and soil inventories of radionuclides from Nuclear Weapon Tests in undisturbed locations are well-established (e.g. Pourcelot et al., 2007; Sanchez-Cabeza et al., 2007, for a summary see table 2 in Sutherland, 1996). Our rain-deposition relationships for plutonium [Fig. 5a] and for ${ }^{137}$ Cs [Fig. 5b] in Savoie and Montagne Noire agree well with previous relationships established in neighbouring countries in Ireland by Mitchell et al. (1990) and Germany by Bunzl and Kracke (1988). At both sites, plutonium and ${ }^{137} \mathrm{Cs}$ total inventory are correlated with annual precipitations. For ${ }^{137} \mathrm{Cs}$, where the data set is more complete than for plutonium, the general relationship between ${ }^{137} \mathrm{Cs}$ total inventory $\left(I_{\text {cesium }}\right)$ in $\mathrm{Bq} \mathrm{m}^{-2}$ and MAP in $\mathrm{mm}$ is:

$$
\begin{aligned}
I_{\text {cesium }} & =3.04 \times \mathrm{MAP}-110 \quad\left(n=51 ; r^{2}=0.415, P_{0.05}\right. \\
& <0.01)
\end{aligned}
$$

In order to see if there was a difference between the 2 areas, $I / \mathrm{MAP}_{\text {Savoie }}$ and I/MAPM-Noire ratios were calculated. Median latencies in ratio for $I / \mathrm{MAP}_{\mathrm{M} \text {-Noire }}$ and, $I / \mathrm{MAP}_{\text {Savoie }}$ are respectively 2.91 and $2.59 \mathrm{~Bq} \mathrm{~m}^{-2} \mathrm{~mm}^{-1}$; the distributions in the two groups of I/MAP ratios are slightly different (Mann-Whitney test $U=382, n_{\text {Mt_Noire }}=21, n_{\text {Savoie }}=27, P=0.041<0.05$, two-tailed . Indeed excluding samples from one site in Savoie like Cormet de Roselend for example will make the relationships for the 2 areas statistically identical (Mann-Whitney test $U=150, n_{\text {Mt_Noire }}=21$, $n_{\text {Savoie }}=21, P=0.08>0.05$, two-tailed $)$.

The slight differences between the two locations can be perhaps explained by the difference in altitude range and topographic features of the 2 areas. For example, high-altitude soils either in Montagne Noire (around $1400 \mathrm{mmy}^{-1}$ precipitations corresponding to the altitude of around $1000 \mathrm{~m}$ ) or in Savoie ( 2 sites: $1850 \mathrm{mmy}^{-1}, 8696 \mathrm{~Bq} \mathrm{~m}^{-2} ; 1808 \mathrm{mmy}^{-1}, 7039 \mathrm{~Bq} \mathrm{~m}^{-2}$ ) have larger inventories than predicted by "classical annual precipitation-deposition relationship" [Fig. 5b, ESI 3]. This can be due to snow accumulation (Pourcelot et al., 2003) or atmospheric processes such as orographic deposition (Le Roux et al., 2008), which are not well taken into account in the AURELHY method to spatialize annual precipitations. These different hypotheses should be further investigated, for example in Pyrenees mountain range.

\subsection{Chronology of radionuclide deposition and comparison with} other records

The age dating of the peat core was done using the ${ }^{210} \mathrm{~Pb}$ Constant Rate of Supply (CRS) model (Appleby, 2001). The peak of 
Table 1

Sample geographic coordinates, radionuclide inventories and ratios.

\begin{tabular}{|c|c|c|c|c|c|c|c|c|c|c|}
\hline Mountainous area & Location & Site number & $\begin{array}{l}\text { Sample } \\
\text { type }\end{array}$ & Latitude & Longitude & $\begin{array}{l}\text { Altitude } \\
(\mathrm{m})\end{array}$ & $\begin{array}{l}\text { Mean annual } \\
\text { precipitation } \\
\text { rate }\left(\mathrm{mm} \mathrm{y}^{-1}\right)\end{array}$ & $\begin{array}{l}{ }^{137} \mathrm{Cs} \\
\text { inventory } \\
\left(\mathrm{Bq} \mathrm{m}^{-2}\right)\end{array}$ & $\begin{array}{l}\Delta^{137} \mathrm{Cs} \\
\text { inventory } \\
\left(\mathrm{Bq} \mathrm{m}^{-2}\right)\end{array}$ & $\begin{array}{l}{ }^{241} \mathrm{Am} \\
\text { inventory } \\
\left(\mathrm{Bq} \mathrm{m}^{-2}\right)\end{array}$ \\
\hline \multirow[t]{21}{*}{ Montagne Noire } & Pic de Nore & PICNO2004-1 & woodland & 43.4185 & 2.4663 & 1112 & 1500 & 6348 & 292 & 73 \\
\hline & Castan & CASTA2004-2 & woodland & 43.4063 & 2.493 & 635 & 1480 & 3582 & 106 & \\
\hline & Pradelles-Cabardès & PRACA2004-2 & woodland & 43.4059 & 2.4324 & 814 & 1350 & 4411 & 259 & \\
\hline & Les Martys & MARTY2004-4 & woodland & 43.4172 & 2.2851 & 793 & 1390 & 5867 & 238 & \\
\hline & Mas-Cabardès & MASCA2004-5 & woodland & 43.3665 & 2.3685 & 357 & 920 & 2343 & 145 & 28 \\
\hline & Limousis & LIMOU2004-6 & woodland & 43.3187 & 2.3987 & 240 & 738 & 2555 & 108 & 30 \\
\hline & Lespinassière & SPINA2004-7 & woodland & 43.4077 & 2.5373 & 610 & 1390 & 3848 & 261 & 45 \\
\hline & Col de Salette & COLSA2004-8 & woodland & 43.422 & 2.5668 & 920 & 1420 & 6865 & 398 & \\
\hline & Col de Salette & COLSA2004-9 & grassland & 43.422 & 2.5668 & 920 & 1420 & 4646 & 170 & \\
\hline & Cassagnoles & CASSA2004-11 & woodland & 43.3829 & 2.621 & 485 & 1200 & 3775 & 203 & \\
\hline & Cassagnoles & CASSA2004-12 & woodland & 43.3829 & 2.621 & 690 & 1200 & 3448 & 125 & \\
\hline & Cassagnoles & CASSA2004-13 & grassland & 43.3829 & 2.621 & 690 & 1220 & 2951 & 119 & \\
\hline & Cassagnoles & CASSA2004-14 & grassland & 43.3829 & 2.621 & 526 & 1080 & 3144 & 207 & \\
\hline & Cassagnoles & CASSA2004-15 & grassland & 43.3829 & 2.621 & 382 & 1200 & 3309 & 235 & \\
\hline & Cassagnoles & CASSA2005-1 & woodland & 43.3829 & 2.621 & 524 & 1200 & 2361 & 163 & \\
\hline & Pic de Nore & PICNO2005-2 & grassland & 43.4185 & 2.4663 & 1180 & 1500 & 5889 & 507 & \\
\hline & $\begin{array}{l}\text { Le Fournas, Ferrals-Les- } \\
\text { Montagnes }\end{array}$ & FOURN2005-4 & grassland & 43.4375 & 2.6175 & 763 & 1380 & 3839 & 306 & \\
\hline & $\begin{array}{l}\text { Le Fournas, Ferrals-Les- } \\
\text { Montagnes }\end{array}$ & FOURN2005-7 & woodland & 43.4375 & 2.6175 & 761 & 1380 & 4812 & 386 & \\
\hline & Pradelles-Cabardès & PRACA2005-8 & grassland & 43.4059 & 2.4324 & 718 & 1350 & 5676 & 308 & \\
\hline & Les Martys & MARTY2005-11 & grassland & 43.4172 & 2.2851 & 794 & 1390 & 3752 & 267 & \\
\hline & Mas-Cabardès & MASCA2005-A12 & grassland & 43.3665 & 2.373 & 299 & 920 & 2352 & 233 & \\
\hline \multirow[t]{28}{*}{$\underline{\text { Savoie }}$} & Courchevel & COURC2006-2 & grassland & 45.39387 & 6.6327 & 2060 & 1368 & 2291 & 272 & 37 \\
\hline & Courchevel & COURC2006-3 & grassland & 45.40036 & 6.63788 & 1913 & 1284 & 3190 & 384 & 45 \\
\hline & Saint Bon & STBON2006-4 & grassland & 45.431715 & 6.634648 & 1199 & 945 & 1619 & 269 & 21 \\
\hline & Saint Bon & STBON2006-5 & grassland & 45.427347 & 6.638135 & 1401 & 980 & 3386 & 398 & 34 \\
\hline & Saint Bon & STBON2006-6 & grassland & 45.427347 & 6.638135 & 1401 & 980 & 2970 & 358 & 58 \\
\hline & Versoye & VERSO2006-7 & grassland & 45.664478 & 6.796135 & 1698 & 1550 & 4014 & 535 & 43 \\
\hline & Versoye & VERSO2006-8 & grassland & 45.663722 & 6.800828 & 1557 & 1537 & 3434 & 479 & 44 \\
\hline & Versoye & VERSO2006-9 & grassland & 45.663612 & 6.80061 & 1547 & 1535 & 4877 & 597 & 54 \\
\hline & Versoye & VERSO2006-10 & grassland & 45.658563 & 6.79606 & 1392 & 1459 & 3411 & 408 & 42 \\
\hline & Bonneval & BONNL2006-11 & grassland & 45.653383 & 6.787328 & 1080 & 1340 & 3228 & 342 & 48 \\
\hline & La Plagne & PLAGN2006-12 & grassland & 45.50395 & 6.69279 & 2145 & 1368 & 3256 & 316 & 46 \\
\hline & La Plagne & PLAGN2006-14 & grassland & 45.50395 & 6.69279 & 2145 & 1368 & 3300 & 417 & 41 \\
\hline & La Plagne & PLAGC2006-15 & grassland & 45.514468 & 6.675112 & 1817 & 1299 & 2967 & 368 & 43 \\
\hline & La Plagne & PLAGC2006-17 & grassland & 45.52547 & 6.67322 & 1521 & 1122 & 2808 & 350 & 38 \\
\hline & Saint Bon & STBON2006-18 & grassland & 45.44318 & 6.638212 & 820 & 908 & 3141 & 379 & 43 \\
\hline & Villarlurin & VILLR2006-19 & grassland & 45.46491 & 6.530807 & 559 & 906 & 3066 & 332 & 42 \\
\hline & Macôt la Plagne & BONNG2006-20 & grassland & 45.543362 & 6.650897 & 1030 & 912 & 3042 & 363 & 45 \\
\hline & Macôt la Plagne & BONNG2006-21 & grassland & 45.550247 & 6.664133 & 725 & 777 & 2247 & 331 & 34 \\
\hline & Col du Petit St Bernard & ROS2006-22 & grassland & 45.67702 & 6.8808 & 2175 & 1808 & 7039 & 670 & 71 \\
\hline & Col du Petit St Bernard & ROS2006-24 & grassland & 45.6616 & 6.86561 & 2006 & 1648 & 5205 & 519 & 77 \\
\hline & Cormelet de Roselend & ROS2006-25 & grassland & 45.69171 & 6.8771 & 1973 & 1850 & 8686 & 930 & 144 \\
\hline & Cormelet de Roselend & ROS2006-26 & grassland & 45.689886 & 6.68793 & 1962 & 1922 & 3910 & 404 & 62 \\
\hline & Cormelet de Roselend & ROS2006-27 & grassland & 45.69829 & 6.69401 & 1996 & 1905 & 4627 & 527 & 70 \\
\hline & Cormelet de Roselend & ROS2006-29 & grassland & 45.69554 & 6.72371 & 1721 & 1896 & 3768 & 417 & 54 \\
\hline & Cormelet de Roselend & ROS2006-30 & grassland & 45.66628 & 6.77428 & 1200 & 1644 & 4385 & 478 & 63 \\
\hline & Cormelet de Roselend & ROS2006-31 & grassland & 45.62704 & 6.78608 & 886 & 997 & 2580 & 338 & 62 \\
\hline & La Rosière & ROS2006-32 & grassland & 45.62587 & 6.83579 & 1564 & 1037 & 3641 & 446 & 44 \\
\hline & Col du Petit St Bernard & PSB-II & peatland & 45.680287 & 6.883954 & 2050 & 1922 & 2910 & 200 & $82^{\mathrm{a}}$ \\
\hline
\end{tabular}

${ }^{\mathrm{a}}$ Measured by gamma spectrometry. 


\begin{tabular}{|c|c|c|c|c|c|c|c|c|c|c|}
\hline $\begin{array}{l}\Delta^{241} \mathrm{Am} \\
\text { inventory } \\
\left(\mathrm{Bq} \mathrm{m}^{-2}\right)\end{array}$ & $\begin{array}{l}{ }^{238} \mathrm{Pu} \\
\text { inventory } \\
\left(\mathrm{Bq} \mathrm{m}^{-2}\right)\end{array}$ & $\begin{array}{l}\Delta^{238} \mathrm{Pu} \\
\text { inventory } \\
\left(\mathrm{Bq} \mathrm{m}^{-2}\right)\end{array}$ & $\begin{array}{l}{ }^{239+240} \mathrm{Pu} \\
\text { inventory } \\
\left(\mathrm{Bq} \mathrm{m}^{-2}\right)\end{array}$ & $\begin{array}{l}\Delta^{239+240} \mathrm{Pu} \\
\text { inventory } \\
\left(\mathrm{Bq} \mathrm{m}^{-2}\right)\end{array}$ & $\begin{array}{l}{ }^{239+240} \mathrm{Pu}^{\prime} \\
{ }^{137} \mathrm{Cs}\end{array}$ & $\begin{array}{l}\Delta^{239+240} \\
\mathrm{Pu}^{/ 137} \mathrm{Cs}\end{array}$ & $\begin{array}{l}{ }^{238} \mathrm{Pu} / \\
{ }^{239}+240 \\
\mathrm{Pu}\end{array}$ & $\begin{array}{l}{ }^{239} \mathrm{238} \mathrm{Pu} / \\
{ }^{240} \mathrm{Pu}\end{array}$ & $\begin{array}{l}{ }^{241} \mathrm{Am} / \\
{ }^{239+240} \mathrm{Pu}\end{array}$ & $\begin{array}{l}\Delta^{241} \mathrm{Am} / \\
{ }^{239+240} \mathrm{Pu}\end{array}$ \\
\hline 7 & 5.5 & 0.5 & 190 & 8 & 0.030 & 0.003 & 0.029 & 0.004 & 0.39 & 0.05 \\
\hline 3 & 2.0 & 0.3 & 76 & 4 & 0.032 & 0.004 & 0.027 & 0.005 & 0.37 & 0.06 \\
\hline 3 & 2.2 & 0.4 & 82 & 4 & 0.032 & 0.003 & 0.027 & 0.006 & 0.37 & 0.06 \\
\hline 5 & 3.0 & 0.4 & 111 & 4 & 0.029 & 0.003 & 0.027 & 0.004 & 0.41 & 0.06 \\
\hline
\end{tabular}

\begin{tabular}{|c|c|c|c|c|c|c|c|c|c|c|}
\hline 4 & 2.3 & 0.4 & 89 & 4 & 0.039 & 0.006 & 0.026 & 0.005 & 0.41 & 0.07 \\
\hline 5 & 3.1 & 0.5 & 111 & 5 & 0.035 & 0.006 & 0.028 & 0.006 & 0.40 & 0.06 \\
\hline 3 & 1.5 & 0.3 & 49 & 2 & 0.030 & 0.006 & 0.031 & 0.007 & 0.42 & 0.07 \\
\hline 4 & 3.3 & 0.5 & 121 & 5 & 0.036 & 0.006 & 0.028 & 0.006 & 0.28 & 0.05 \\
\hline 6 & 2.8 & 0.5 & 100 & 4 & 0.034 & 0.006 & 0.028 & 0.006 & 0.58 & 0.08 \\
\hline 6 & 3.2 & 0.5 & 112 & 5 & 0.028 & 0.005 & 0.028 & 0.006 & 0.38 & 0.07 \\
\hline 8 & 3.0 & 0.8 & 107 & 6 & 0.031 & 0.006 & 0.028 & 0.009 & 0.41 & 0.10 \\
\hline 7 & 4.4 & 0.7 & 132 & 6 & 0.027 & 0.004 & 0.033 & 0.006 & 0.41 & 0.07 \\
\hline 5 & 3.4 & 0.7 & 106 & 6 & 0.031 & 0.005 & 0.032 & 0.008 & 0.40 & 0.07 \\
\hline 5 & 3.7 & 0.6 & 113 & 5 & 0.035 & 0.005 & 0.033 & 0.007 & 0.42 & 0.06 \\
\hline 4 & 2.8 & 0.3 & 107 & 4 & 0.033 & 0.004 & 0.026 & 0.004 & 0.43 & 0.06 \\
\hline 5 & 2.5 & 0.4 & 100 & 4 & 0.030 & 0.005 & 0.025 & 0.005 & 0.41 & 0.06 \\
\hline 5 & 2.9 & 0.4 & 103 & 4 & 0.035 & 0.006 & 0.029 & 0.005 & 0.42 & 0.07 \\
\hline 6 & 2.6 & 0.4 & 94 & 4 & 0.034 & 0.006 & 0.028 & 0.006 & 0.41 & 0.08 \\
\hline 6 & 3.2 & 0.4 & 106 & 4 & 0.034 & 0.005 & 0.030 & 0.005 & 0.40 & 0.07 \\
\hline 5 & 2.9 & 0.4 & 107 & 4 & 0.035 & 0.005 & 0.027 & 0.005 & 0.40 & 0.06 \\
\hline 5 & 2.8 & 0.5 & 104 & 4 & 0.034 & 0.006 & 0.027 & 0.006 & 0.43 & 0.07 \\
\hline 4 & 2.6 & 0.4 & 81 & 4 & 0.036 & 0.007 & 0.032 & 0.007 & 0.41 & 0.07 \\
\hline 7 & 5.2 & 0.4 & 183 & 7 & 0.026 & 0.003 & 0.029 & 0.003 & 0.39 & 0.05 \\
\hline 7 & 5.1 & 0.5 & 194 & 7 & 0.037 & 0.005 & 0.026 & 0.003 & 0.40 & 0.05 \\
\hline 12 & 8.6 & 0.6 & 350 & 11 & 0.040 & 0.006 & 0.025 & 0.003 & 0.41 & 0.05 \\
\hline 7 & 4.2 & 0.5 & 146 & 5 & 0.037 & 0.005 & 0.029 & 0.005 & 0.43 & 0.06 \\
\hline 7 & 4.7 & 0.5 & 164 & 6 & 0.035 & 0.005 & 0.029 & 0.004 & 0.43 & 0.06 \\
\hline 6 & 3.3 & 0.5 & 124 & 5 & 0.033 & 0.005 & 0.026 & 0.005 & 0.43 & 0.06 \\
\hline 6 & 4.6 & 0.7 & 151 & 6 & 0.035 & 0.005 & 0.030 & 0.006 & 0.42 & 0.06 \\
\hline 7 & 4.9 & 1.0 & 154 & 8 & 0.060 & 0.011 & 0.032 & 0.008 & 0.40 & 0.06 \\
\hline 5 & 3.2 & 0.4 & 111 & 4 & 0.031 & 0.005 & 0.029 & 0.005 & 0.39 & 0.06 \\
\hline 30 & & & & & & & & & & \\
\hline
\end{tabular}




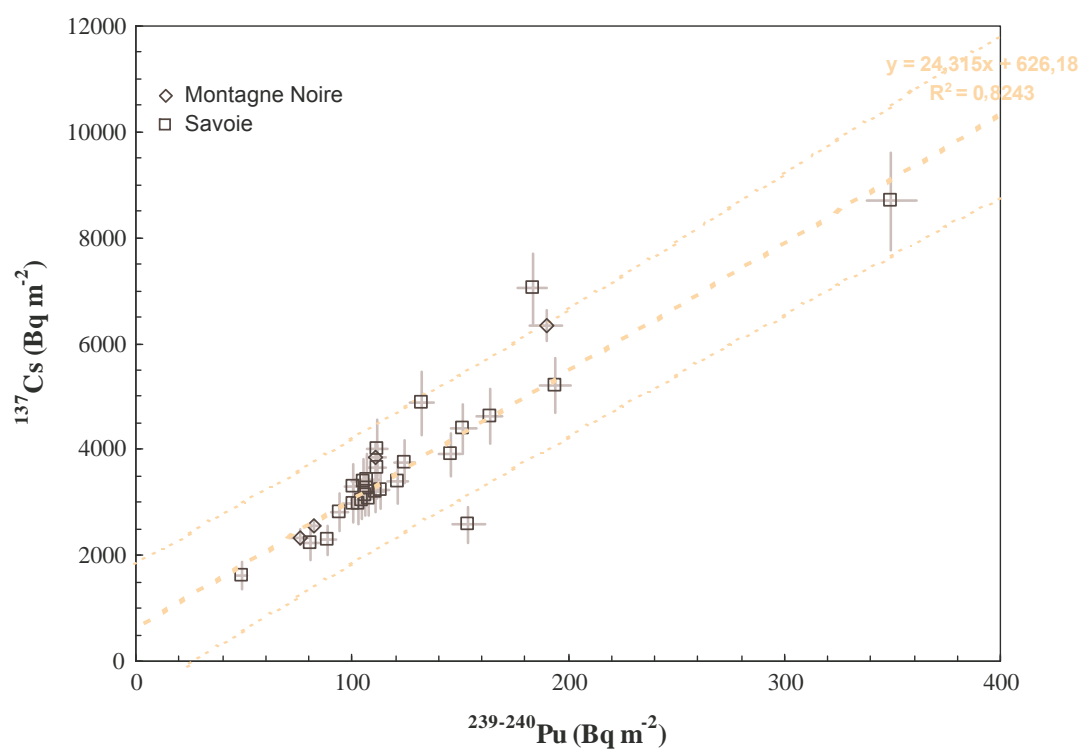

Fig. 2. Relationship between ${ }^{137} \mathrm{Cs}$ and ${ }^{239+240} \mathrm{Pu}$ total soil inventories in Savoie (squares) and Montagne Noire (diamonds).

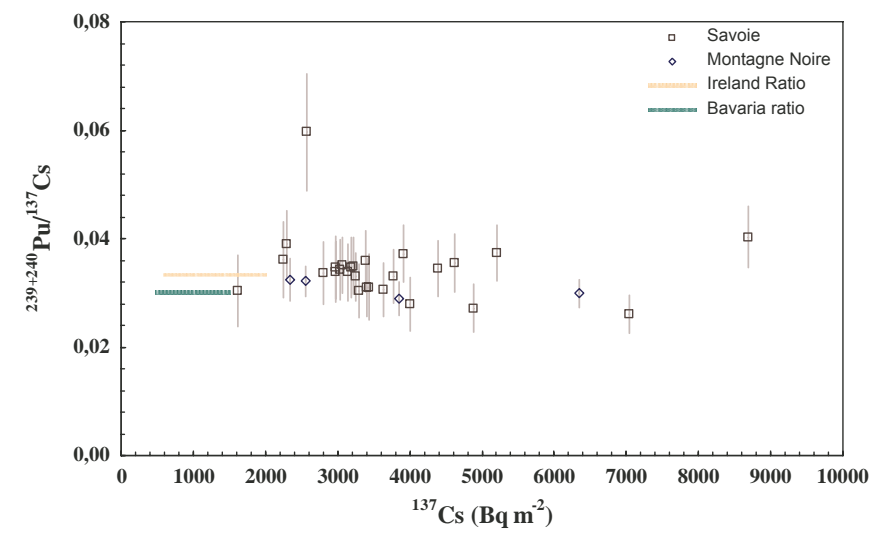

Fig. 3. ${ }^{239+240} \mathrm{Pu} /{ }^{137} \mathrm{Cs}$ ratio vs. ${ }^{137} \mathrm{Cs}$ in total soil inventories in Montagne Noire (diamonds) and Savoie (squares).

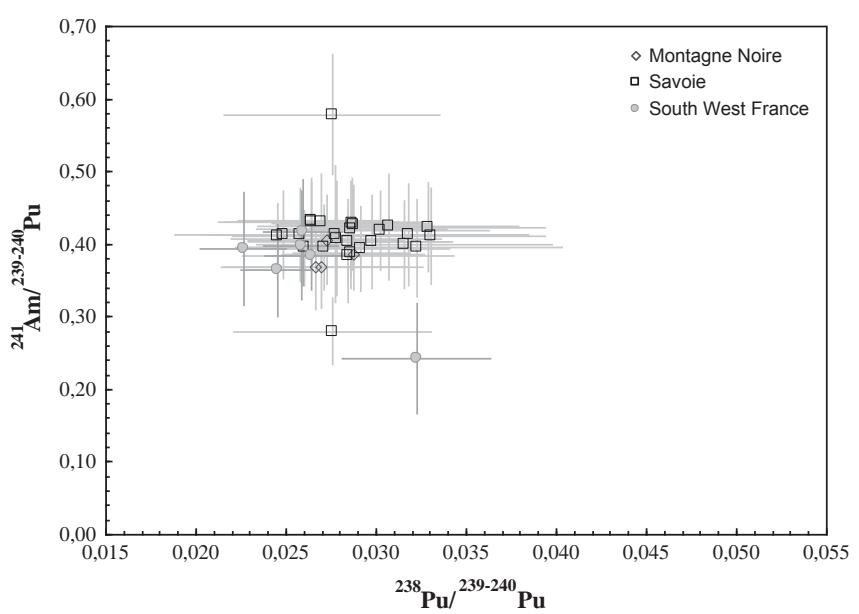

Fig. 4. ${ }^{241} \mathrm{Am} /{ }^{239+240} \mathrm{Pu}$ vs. ${ }^{238} \mathrm{Pu} /{ }^{239+240} \mathrm{Pu}$ in total soil inventories in Montagne Noire (diamonds) and Savoie (squares). Are also shown 6 samples from South-West France (full circles - unpublished data IRSN). 

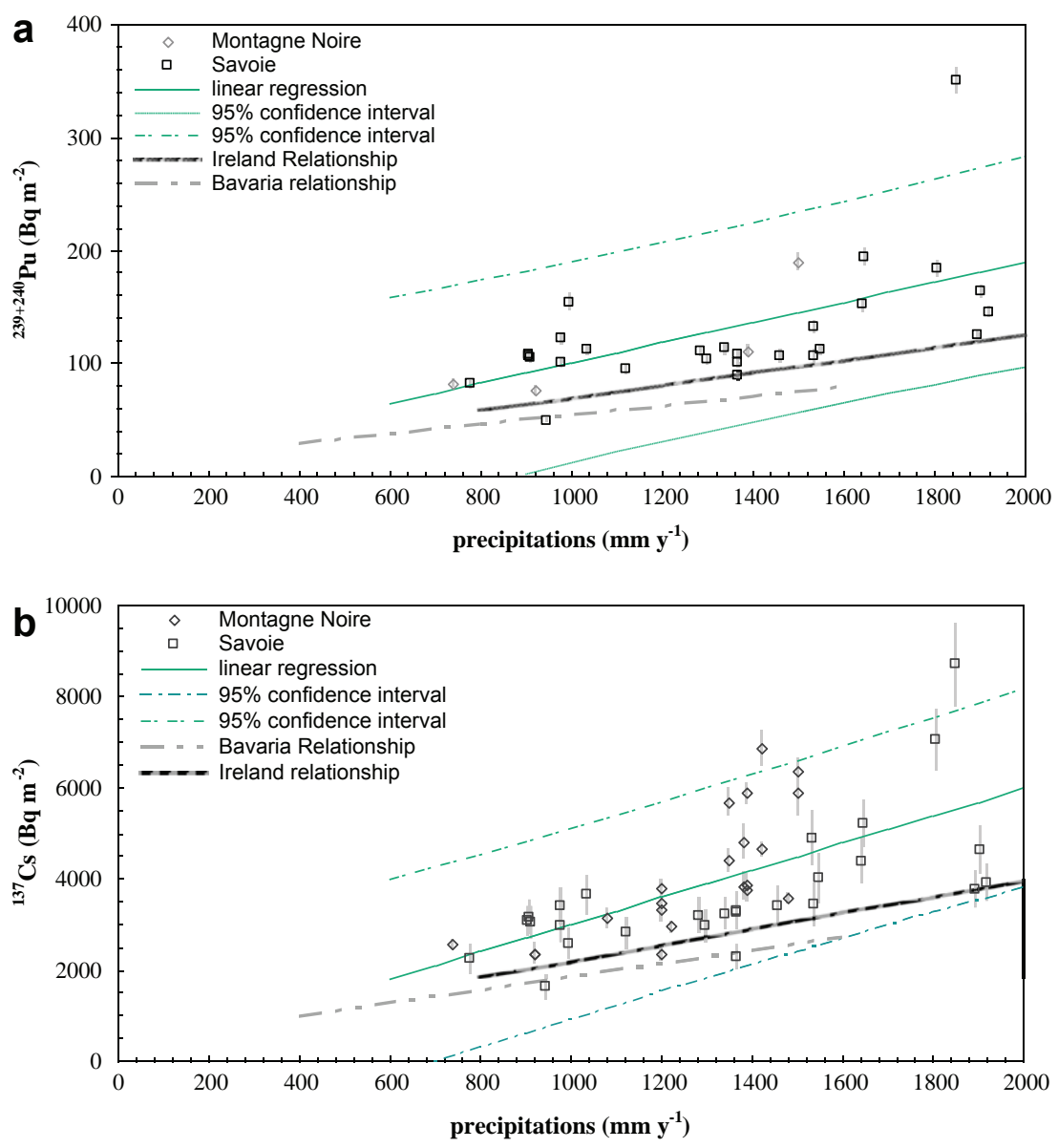

Fig. 5. a. relationship between ${ }^{137} \mathrm{Cs}$ total soil inventories and annual precipitations in Savoie (squares), in Montagne Noire (diamonds). b. relationship between ${ }^{239+240}$ Pu total soil inventories and annual precipitations in Savoie (squares), in Montagne Noire (diamonds).

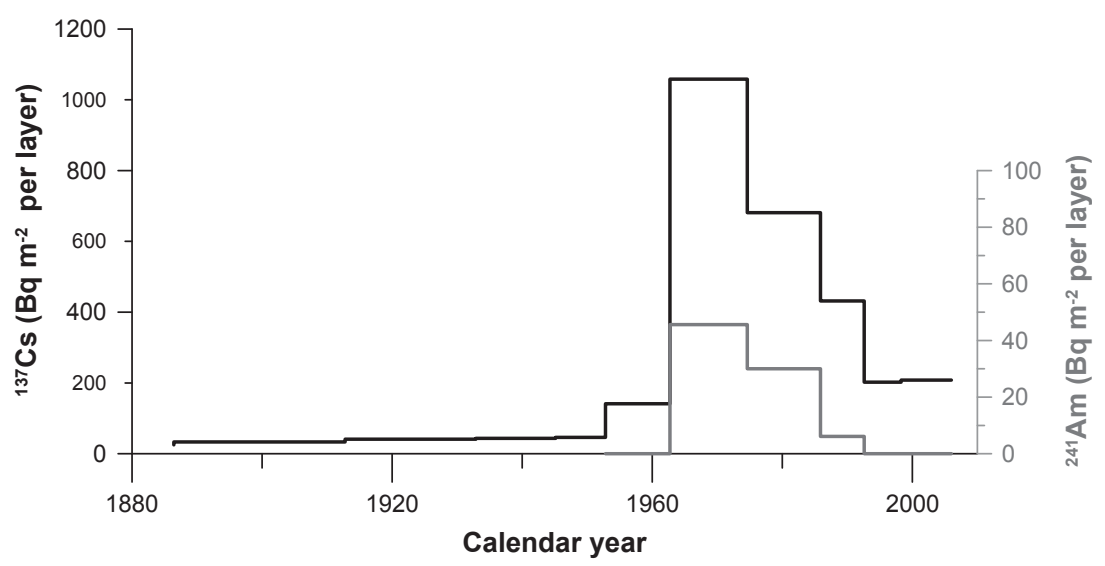

Fig. 6. ${ }^{137} \mathrm{Cs}$ and ${ }^{241} \mathrm{Am}$ distribution (Bq $\mathrm{m}^{-2}$ per layer) vs. calendar age estimated by ${ }^{210} \mathrm{~Pb} \mathrm{CRS}$ model.

${ }^{137}$ Cs and ${ }^{241} \mathrm{Am}$ is dated between 1963 and 1975 [Fig. 6], which is in good agreement with records in western Europe (Monna et al., 2009 - Fig. 1). ${ }^{137}$ Cs is subject of mobilization in the peat core because of similar behaviour than $\mathrm{K}^{+}$and plant retention (Turetsky et al., 2004; Rausch et al., 2005), however ${ }^{241} \mathrm{Am}$, daughter of ${ }^{241} \mathrm{Pu}$ is relatively immobile with only three peat layers where this radionuclide is measurable. Mobility of ${ }^{137} \mathrm{Cs}$ in the peat core can perhaps explain the low ${ }^{137} \mathrm{Cs}$ inventory $\left(2910 \mathrm{~Bq} \mathrm{~m}^{-2}\right)$ in comparison with nearby soils $\left(5200-7000 \mathrm{~Bq} \mathrm{~m}^{-2}\right) .{ }^{241} \mathrm{Am}$ soil inventory, as measured by gamma spectrometry, is $82 \mathrm{~Bq} \mathrm{~m}^{-2}$. This is in good agreement with nearby soil inventories for ${ }^{241} \mathrm{Am}$ (71$77 \mathrm{~Bq} \mathrm{~m}^{-2}$ ).

\section{Conclusions}

Our results on deposition of artificial radionuclides in two mountainous areas not impacted by Chernobyl-derived radionuclides, show that deposition over a large spectrum of precipitation 
rate is mainly explained by mean annual precipitation in good agreement with previous European studies. In high mountainous sites, radionuclide soil inventory in soils can be higher than predicted due to snow accumulation and orographic precipitations. Isotopic ratio of ${ }^{137} \mathrm{Cs},{ }^{241} \mathrm{Am}$ and plutonium isotopes confirm their Global Fallout origin. ${ }^{241} \mathrm{Am}$ and ${ }^{137} \mathrm{Cs}$ peaks found in peat layer agedated from the end of the sixties to beginning of the seventies confirm that radionuclides were deposited following the Nuclear Weapon tests.

\section{Acknowledgements}

We would like to thank J. Marquet, G. Salaun and F. Danic for help during the different field trips; B. Besson for help in statistics, $\mathrm{X}$. Cagnat, C. Cossonet and R. Gurrarian for analysis from the LMRE and William Shotyk for use of "the peat preparation room" at Heidelberg. Constructive comments provided by two anonymous reviewers are acknowledged.

\section{Appendix. Supplementary data}

Supplementary data associated with this article can be found, in the online version, at doi:10.1016/j.jenvrad.2009.10.010.

\section{References}

Almgren, S., Nilsson, E., Erlandsson, B., Isaksson, M., 2006. GIS supported calculations of ${ }^{137} \mathrm{Cs}$ deposition in Sweden based on precipitation data. Science of the Total Environment 368 (2-3), 804-813.

Aoyama, M., Hirose, K., Igarashi, 2006. Re-construction and updating our understanding on the global weapons tests ${ }^{137} \mathrm{Cs}$ fallout. Journal of Environmental Monitoring 8 (4), 431-438.

Appleby, P.G., 2001. Chronostratigraphic techniques in recent sediments. In Tracking Environmental Change Using Lake Sediments. Basin Analysis, Coring, and Chronological Techniques. In: Developments in Paleoenvironmental Research, vol. 1, pp. 171-203.

Bénichou, P., Le Breton, O., 1986. Prise en compte de la topographie pour la cartographie des champs pluviométriques statistiques: la méthode AURELHY. Agrométéorologie des régions de moyennes montagnes. INRA 39, 51-68.

Bénichou, P., Le Breton, O., 1987. Prise en compte de la topographie pour la cartographie des champs pluviométriques statistiques. (Taking into account the topography for the cartography of statistical rainfall fields). La Météorologie 7 23-24.

Bouisset, P. Calmet, D., 1997. Hyper pure gamma-ray spectrometry applied to lowlevel environmental sample measurement. In: International Workshop on the Status of Measurement Techniques for the Identification of Nuclear Signatures, pp. 73-81.

Bunzl, K., Kracke, W., 1988. Cumulative deposition of ${ }^{137} \mathrm{Cs},{ }^{238} \mathrm{Pu},{ }^{239+240} \mathrm{Pu}$ and ${ }^{241} \mathrm{Am}$ from global fallout in soils from forest, grassland and arable land in Bavaria (FRG). Journal of Environmental Radioactivity 8 (1), 1-14.

CRIIRAD, Commission de Recherche et d'Information Indépendante sur la Radioactivité, 2003, Synthèse des mesures de la radioactivité réalisées en Montagne Noire, v. 3, 7 pp.

Daly, G., Wania, F., 2005. Organic contaminants in mountains. Environmental Science and Technology 39 (2), 385-398.

Eikenberg, J., Beer, H., Bajo, S., 2004. Anthropogenic radionuclide emissions into the environment. In: The Nuclear Fuel Cycle. Geological Society, London, Special Publications, vol. 236, pp. 143-151. London.

Froidevaux, P., Dlala, J., Barraud, F., Valley, J.-F., 2004. Mesures de plutonium et d'américium dans l'environnement. In: Radioactivité de l'environnement e dose de rayonnement en Suisse. Federal Office of Public Health, 3003 Bern,
Switzerland. Available from: http://www.bag.admin.ch/themen/strahlung/ 00043/00065/02239 (in French) chapter 7.3.

Givelet, N., Le Roux, G., Cheburkin, A., Chen, B., Frank, J., Goodsite, M., Kempter, H. Krachler, M., Noernberg, T., Rausch, N., Rheinberger, S., Roos-Barraclough, F., Sapkota, A., Scholz, C., Shotyk, W., 2004. Suggested protocol for collecting, handling and preparing peat cores and peat samples for physical, chemical, mineralogical and isotopic analyses. Journal of Environmental Monitoring 6 (5), 481-492.

Goutelard, F., Morello, M., Calmet, D., 1998. Alpha-spectrometry measurement of $\mathrm{Am}$ and $\mathrm{Cm}$ at trace levels in environmental samples using extraction chromatography. Journal of Alloys and Compounds 271-273, 25-30.

Graustein, W.C., Turekian, K.K., 1989. The effects of forests and topography on the deposition of sub-micrometer aerosols measured by lead-210 and cesium-137 in soils. Agricultural \& Forest Meteorology $47(2-4), 199-220$.

Hardy, E.P., Krey, P., Volchok, H.L., 1973. Global inventory and distribution of fallout plutonium. Nature 241, 444-445.

Hodge, V., Smith, C., Whiting, J., 1996. Radiocesium and plutonium: still together in "background" soils after more than thirty years. Chemosphere 32 (10), 2067-2075.

Jia, G., Testa, C., Desideri, D., Guerra, F., Meli, M.A., Roselli, C., Belli, M.E., 1999. Soil concentration, vertical distribution and inventory of plutonium, ${ }^{241} \mathrm{Am},{ }^{90} \mathrm{Sr}$ and ${ }^{137} \mathrm{Cs}$ in the Marche region of central Italy. Health Physics 77, 52-61.

Le Roux, G., Pourcelot, L., Masson, O., Duffa, C., Vray, F., Renaud, P., 2008. Aerosol deposition and origin in French mountains estimated with soil inventories of ${ }^{210} \mathrm{~Pb}$ and artificial radionuclides. Atmospheric Environment 42 (7), 1517-1524.

Mitchell, P.I., Sanchez-Cabeza, J.A., Ryan, T.P., Mcgarry, A.T., 1990. Preliminary estimates of cumulative caesium and plutonium deposition in the Irish terrestrial environment. Journal of Radioanalytical and Nuclear Chemistry 138 (2), 241-256.

Monna, F., van Oort, F., Hubert, P., Dominik, J., Bolte, J., Loizeau, J.-L., Labanowski, J., Lamri, J., Petit, C., Le Roux, G., Château, C., 2009. Modeling of 137Cs migration in soils using an 80-year soil archive: role of fertilizers and agricultural amendments. Journal of Environmental Radioactivity 100 (1), 9-16.

Pourcelot, L., Louvat, D., Gauthier-Lafaye, F., Stille, P., 2003. Formation of radioactivity enriched soils in mountain areas. Journal of Environmental Radioactivity 68 (3), 215-233.

Pourcelot, L., Steinmann, P., Froidevaux, P., 2007. Lower variability of radionuclide activities in upland dairy products compared to soils and vegetation: implication for environmental survey. Chemosphere 66 (8), 1571-1579.

Rausch, N., Nieminen, T., Ukonmaanaho, L., Le Roux, G., Krachler, M. Cheburkin, A.K., Bonani, G., Shotyk, W., 2005. Comparison of atmospheric deposition of copper, nickel, cobalt, zinc, and cadmium recorded by Finnish peat cores with monitoring data and emission records. Environmental Science and Technology 39 (16), 5989-5998.

Renaud, P., Pourcelot, L., Métivier, J.-M., Morello, M., 2003. Mapping of ${ }^{137} \mathrm{Cs}$ deposition over eastern France 16 years after the Chernobyl accident. Science of the Total Environment 309 (1-3), 257-264.

Renaud, P., Métivier, J.M., Castelier, L., Pourcelot, L., Louvat, D., 2004. Cartographie des dépôts de ${ }^{137}$ Cs en mai 1986 sur l'ensemble du territoire français métropolitain. Radioprotection 39, 23-38.

Renaud, P., Garcia-Sanchez, L., Métivier, J.M., Pourcelot, L., Champion, D., 2005 Phenomenological and analytical interpretation of the rain-deposit relation used for the reconstitution of the previous 137Cs next term deposits in France after the Chernobyl accident. IRSN Report 2005-03.

Roe, G.H., 2005. Orographic precipitation. Annual Review of Earth and Planetary Sciences 33, 645-671.

Roussel-Debet, S., Renaud, P., Métivier, J.M., 2007. ${ }^{137}$ Cs in French soils: deposition patterns and 15-year evolution. Science of The Total Environment 374 (2-3) 388-398.

Sanchez-Cabeza, J.A., Garcia-Talavera, M., Costa, E., Peña, V., Garcia-Orellana, J. Masqué, P., Nalda, C., 2007. Regional calibration of erosion radiotracers (210Pb and $137 \mathrm{Cs}$ ): atmospheric fluxes to soils (northern Spain). Environmental Science \& Technology 41 (4), 1324-1330.

Sutherland, R.A., 1996. Caesium-137 soil sampling and inventory variability in reference locations: a literature survey. Hydrological Processes 10 (1), 43-53.

Turetsky, M.R., Manning, S.M., Wieder, R.K., 2004. Dating recent peat deposits. Wetlands 24 (2), 324-356. 